\title{
Phosphodiesterase 1B Knock-Out Mice Exhibit Exaggerated Locomotor Hyperactivity and DARPP-32 Phosphorylation in Response to Dopamine Agonists and Display Impaired Spatial Learning
}

\author{
Tracy M. Reed, ${ }^{1,3}$ David R. Repaske, ${ }^{2 *}$ Gretchen L. Snyder, ${ }^{4}$ Paul Greengard, ${ }^{4}$ and Charles V. Vorhees ${ }^{1 *}$

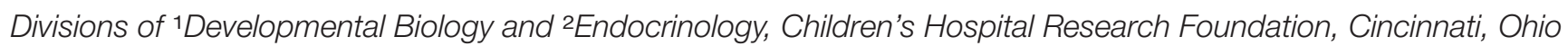 \\ 45229, ${ }^{3}$ Department of Biology, College of Mount St. Joseph, Cincinnati, Ohio 45233, and 4 Laboratory of Molecular and \\ Cellular Neuroscience, Rockefeller University, New York, New York 10021
}

\begin{abstract}
Using homologous recombination, we generated mice lacking phosphodiesterase-mediated (PDE1B) cyclic nucleotidehydrolyzing activity. PDE1B ${ }^{-1-}$ mice showed exaggerated hyperactivity after acute D-methamphetamine administration. Striatal slices from PDE1B ${ }^{-/-}$mice exhibited increased levels of phospho-Thr ${ }^{34}$ DARPP-32 and phospho-Ser ${ }^{845}$ GluR1 after dopamine D1 receptor agonist or forskolin stimulation. $\mathrm{PDE} 1 \mathrm{~B}^{-/-}$and $\mathrm{PDE} 1 \mathrm{~B}^{+/-}$mice demonstrated Morris
\end{abstract}

Calcium/calmodulin-dependent phosphodiesterases (CaMPDEs) are members of one of 11 families of PDEs (Soderling et al., 1999; Yuasa et al., 2001) and comprise the only family that acts as a potential point of interaction between the $\mathrm{Ca}^{2+}$ and cyclic nucleotide signaling pathways. The three known CaM-PDE genes, PDE1A-C, are expressed within the CNS. PDE1A is expressed throughout the brain, with higher levels in CA1-CA3 and cerebellum and a low level in the striatum (Borisy et al., 1992; Yan et al., 1994). PDE1B is expressed predominantly in the striatum, dentate gyrus, olfactory tract, and cerebellum, regions having high levels of dopaminergic innervation (Furuyama et al., 1994; Polli and Kincaid, 1994; Yan et al., 1994). PDE1C is expressed primarily in olfactory epithelium, cerebellar granule cells, and striatum (Yan et al., 1995, 1996).

The expression of CaM-PDEs in the striatum and evidence indicating that cyclic nucleotides and calcium are principal second messengers of the signal transduction pathways in the striatum (Altar et al., 1990) suggest that CaM-PDEs may play a role in motor control (Traficante et al., 1976; Tsou et al., 1993; Drago et al., 1994; Konradi et al., 1994; Polli and Kincaid, 1994). Furthermore, NMDA receptor activation results in increased intracellular $\mathrm{Ca}^{2+}$ concentrations (Kotter, 1994; Greengard et al., 1999) that activate effectors such as calmodulin-dependent kinase-II

\footnotetext{
Received Oct. 31, 2001; revised March 5, 2002; accepted March 26, 2002.

This work was supported by National Institutes of Health Grants T32 ES07051 (T.M.R.), RO1 DA06733 (C.V.V.), and MH40899 and DA10044 (P.G. and G.L.S.) and by funds from the Children's Hospital Research Foundation (D.R.R.). We thank Dr. Richard L. Huganir for providing the phospho-Ser ${ }^{845}$ GluR1 antibody. The excellent technical assistance of Stacey Galdi is gratefully acknowledged. We also thank Drs. Kenn Holmback and Rebecca Muraoka for technical guidance with the ES cell culture.

*D.R.R. and C.V.V. contributed equally to this work.

Correspondence should be addressed to Dr. Charles V. Vorhees, Division of Developmental Biology, Children's Hospital Research Foundation, 3333 Burnet Avenue, Cincinnati, OH 45229-3039. E-mail: charles.vorhees@chmcc.org. Copyright (C) 2002 Society for Neuroscience $0270-6474 / 02 / 225188-10 \$ 15.00 / 0$
}

maze spatial-learning deficits. These results indicate that enhancement of cyclic nucleotide signaling by inactivation of PDE1B-mediated cyclic nucleotide hydrolysis plays a significant role in dopaminergic function through the DARPP-32 and related transduction pathways.

Key words: phosphodiesterases; DARPP-32; dopaminestimulated locomotor activity; spatial learning and memory; Morris water maze; methamphetamine; SKF81297; forskolin

(CaMKII) and calcineurin and have the potential to activate CaM-PDEs. Dopamine D1 or D2 receptor activation leads to adenylyl cyclase activation or inhibition, respectively (Traficante et al., 1976; Monsma et al., 1990; Cunningham and Kelley, 1993; Miserendino and Nestler, 1995). Intracellular concentrations of cGMP also are increased after dopamine D1 receptor activation and are unchanged or inhibited after D2 receptor activation (Altar et al., 1990). Cyclic nucleotides activate PKA- or PKGdependent protein kinases that phosphorylate downstream signaling elements such as DARPP-32 (dopamine- and cAMPregulated phosphoprotein, $M_{\mathrm{r}} 32 \mathrm{kDa}$ ) and cAMP-responsive element-binding protein (CREB). These signaling pathways are downregulated by PDEs by hydrolysis of the cyclic nucleotides to their 5'-monophosphates. Calcium-regulated PDEs are therefore potential interfaces between dopamine- and glutamate-regulated signaling pathways.

Long-term potentiation (LTP) and long-term depression (LTD), the major forms of plasticity associated with hippocampally mediated learning and memory, also are regulated by cyclic nucleotides and CaM signal transduction cascades, as demonstrated by disruptions that occur in response to changes in protein kinase A (PKA) (Skoulakis et al., 1993; Abel et al., 1997), CaMKII (Bach et al., 1995; Mayford et al., 1995; Malenka and Nicoll, 1999), CREB (Bourtchuladze et al., 1994; Yin et al., 1994; Guzowski and McGaugh, 1997), and calcineurin (Mansuy et al., 1998). Drosophila mutants including dunce, a cAMP-specific PDE mutant (Qui and Davis, 1993), rutabaga, an adenylyl cyclase mutant (Livingstone et al., 1984), and a PKA mutant (Skoulakis et al., 1993) all have shown altered intracellular levels of cAMP or an altered cAMP signaling pathway with concomitant olfactory-conditioning deficits (Davis et al., 1995). cGMP also has been implicated in learning and memory through the nitric oxide retrograde signal transduction pathway (Gally et al., 1990; Garthwaite, 1991). 
A physiological role for the PDEs in the brain has not been established, although PDE4 inhibitors have shown clinical efficacy as antidepressants (Houslay et al., 1998). The localization of PDE1 family members within the striatum, hippocampus, and olfactory tract as well as their ability to interact with two essential signal transduction pathways suggests a potential role for CaMPDEs in motor control, learning, and olfaction. To investigate the role of one of these, we generated mice in which PDE1B was rendered inactive by targeted disruption of the catalytic domain and characterized the mice via tests related to the functions associated with regions in which PDE1B is expressed (locomotor activity for striatum, spatial learning for dentate gyrus, and olfactory orientation for olfactory tract).

\section{MATERIALS AND METHODS}

Gene targeting. Two overlapping clones, TRC2 and TRC4 corresponding to exons 2-13 of the PDE1B gene, were obtained by screening an I-129/SvJ $\lambda$ Dash II mouse genomic library as described previously (Reed et al., 1998). A $0.8 \mathrm{~kb} \mathrm{XbaI}$ fragment containing exons 4 and 5 and a small portion of the multiple cloning site of pBluescript II KS(-) (Stratagene, La Jolla, CA) was blunt end-ligated into the BamHI site of the targeting vector. A $5 \mathrm{~kb} A c c \mathrm{I} / K p n \mathrm{I}$ fragment containing genomic DNA $3^{\prime}$ of exon 9 , including $2.4 \mathrm{~kb}$ of the noncoding sequence $3^{\prime}$ to exon 13 , was blunt end-ligated into the ClaI site of the targeting vector (see Fig. $1 A$ ). The targeting vector backbone pGKKOV has been described previously $(\mathrm{Li}$ et al., 1996). This vector is derived from pBluescript II SK(+), with a herpes simplex virus-thymidine kinase selectable marker and a PGKHPRT selectable marker inserted into the KpnI and HindIII sites, respectively, of the multiple cloning site. The orientation of inserts was determined by sequencing.

The targeting vector $(50 \mu \mathrm{g})$ was linearized with NotI and electroporated into $9.3 \times 10^{6}$ E14TG2a embryonic stem (ES) cells. ES cells were plated on ten $100 \mathrm{~cm}$ tissue culture plates (Fisher Scientific, Houston, TX) on $2.2 \times 10^{6}$ mitomycin C-treated mouse embryonic fibroblasts in 10 $\mathrm{ml}$ of DMEM per plate containing 15\% ES Cell Qualified fetal calf serum (Invitrogen, San Diego, CA), 0.3 mM L-glutamine, 75,000 U of Pen/Strep, $60 \mathrm{U}$ of leukemia inhibitory factor, and $0.009 \%$ $\beta$-mercaptoethanol supplemented with $2 \mu \mathrm{M}$ Cytovene and $1 \times$ hypoxanthine aminopterin thymidine (HAT) (Life Technologies) for the selection process. After $5 \mathrm{~d}$ of selection, $302 \mathrm{ES}$ cell clones were selected and expanded in 24-well plates. Clones were screened by Southern blot analysis. Cells from two positive clones were injected into C57BL/6 blastocysts and implanted into pseudopregnant females. Chimeric offspring were bred to C57BL/6 mice (Charles River, Wilmington, MA) to produce $\mathrm{PDE} 1 \mathrm{~B}^{+/-}$offspring that were bred to $\mathrm{C} 57 \mathrm{BL} / 6$ mice for two additional generations to give a total of three backcross breedings. The offspring resulting from interbreeding the third generation backcross were used for behavioral testing.

Southern blot analysis. Southern blot analysis was performed as described previously (Reed et al., 1998) on StuI or NdeI/KpnI-digested DNA that was purified from ES cells or tail biopsies. Briefly, prehybridization and hybridization were performed at $65^{\circ} \mathrm{C}$ in $1 \%$ SDS, $1 \mathrm{~m} \mathrm{NaCl}$, and $10 \%$ dextran sulfate. Blots were screened with a 347 bp PCR-generated probe corresponding to mouse PDE1B exon 3 and 164 bp of $5^{\prime}$ and $3^{\prime}$ flanking intron sequences, and the probe was outside of the targeted region of the PDE1B gene. PCR primers used were 5'-GACACTAAGTGGGTATAGCTGGGT-3' and 5'-GTGGGAATAAGTCTCAGGGTAGG-3'. Then $25 \mathrm{ng}$ of probe was radiolabeled with ${ }^{32} \mathrm{P}-\mathrm{dCTP}$ by random priming with the Prime-It II Kit (Stratagene), boiled with $5 \mathrm{mg}$ salmon sperm DNA in $500 \mu \mathrm{l}$ of water for $5 \mathrm{~min}$, and added to $30 \mathrm{ml}$ of hybridization buffer. Blots were hybridized for $12-16 \mathrm{hr}$; the final posthybridization wash was in $2 \times$ SSC plus $1 \%$ SDS at $65^{\circ} \mathrm{C}$. Homologous recombination events resulted in size shifts from 3.7 to $2.2 \mathrm{~kb}(S t u \mathrm{I})$ (see Fig. $1 A, B)$ and from 3.7 to 10.6 kb (NdeI/KpnI) (see Fig. 1A).

Northern blot analysis. Total brain RNA was isolated via the TriReagent method (Molecular Research Center, Cincinnati, OH). RNA (10 $\mu \mathrm{g})$ was fractionated on a $1 \%$ denaturing agarose gel and transferred for $24 \mathrm{hr}$ onto a Biotrans nylon membrane (ICN Biochemicals, Aurora, OH) by using $20 \times$ SSC. The blot was prehybridized in $10 \mathrm{ml}$ of solution consisting of $50 \%$ formamide, $50 \mathrm{mM} \mathrm{NaPO}_{4}, 5 \times \mathrm{SSC}, 5 \times$ Denhardt's, $0.5 \% \mathrm{SDS}$, and $1 \%$ glycine with $250 \mu \mathrm{l}$ of $10 \mathrm{mg} / \mathrm{ml}$ salmon sperm DNA at $42^{\circ} \mathrm{C}$ for $4 \mathrm{hr}$. The blot was hybridized with ${ }^{32} \mathrm{P}$-labeled probe K-17, a
348 bp mouse partial PDE1B cDNA corresponding to the central catalytic domain, as described previously (Repaske et al., 1992). The probe was boiled for $5 \mathrm{~min}$ with $100 \mu \mathrm{l}$ of $10 \mathrm{mg} / \mathrm{ml}$ salmon sperm DNA, added to $10 \mathrm{ml}$ of the hybridization buffer of $50 \%$ formamide, $20 \mathrm{mM} \mathrm{NaPO}_{4}$, $5 \times$ SSC, $1 \times$ Denhardt's, $0.5 \%$ SDS, and $10 \%$ dextran sulfate, and incubated at $42^{\circ} \mathrm{C}$ for $21 \mathrm{hr}$. The final posthybridization wash was in $0.1 \times$ SSC plus $0.1 \%$ SDS at $55^{\circ} \mathrm{C}$.

Subjects. Animals used for behavioral analysis were the offspring of the third generation backcrossing $\left(\mathrm{PDE}^{\mathrm{B}} \mathrm{B}^{-1-}, \mathrm{PDE}_{\mathrm{B}}^{+/-}\right.$, mice and their WT littermates), and those for biochemistry were the offspring of third and fourth generation backcrossing. Mice for behavioral analysis were earmarked on postnatal day 7 (P7) and weighed weekly, beginning on P7 and ending on P112. Tail biopsies were obtained on P21 or P42. Litters were weaned on P28. Mice were housed, same gender, two to four mice per cage. Individual mice were excluded from testing if there were no same-gender littermates or if visible ocular defects were present. One experimenter performed all procedures and was blinded to genotypes until the end of the experiment.

Olfactory orientation. On P9, P11, and P13, all offspring in each litter were tested individually for olfactory orientation to their home cage scent as described previously (Acuff-Smith et al., 1992). The apparatus consists of a $12 \times 38 \mathrm{~cm}$ enclosed runway flanked with $30 \times 38 \mathrm{~cm}$ enclosed chambers containing equal amounts of either home bedding or clean bedding. The runway floor was marked every $2.5 \mathrm{~cm}$. The home bedding for each litter was changed on P7. The bedding was not changed again until after testing was completed (P14) and was used on each test day and returned to the home cage. Before individual testing the pups were removed from the dam and placed in a holding cage on a heating pad to maintain body temperature. During the $1 \mathrm{~min} / \mathrm{d}$ test period each mouse was placed in the center of the runway, and head position was scored every $10 \mathrm{sec}$ by using runway positions of +1 to +7 for movement toward the home bedding and -1 to -7 for movement toward the clean bedding. Individual scores were summed for each test day.

Locomotor activity. On P50, P51, or P52, locomotor activity was measured in a $30.5 \times 30.5 \mathrm{~cm}$ Digiscan apparatus containing 16 photo detector-LED pairs along the $x$-axis and 16 pairs along the $y$-axis (model rxy $2 z$, Accuscan Electronics, Columbus, OH). Prechallenge activity was recorded in $3 \mathrm{~min}$ intervals over a $1 \mathrm{hr}$ period. Mice were challenged with a subcutaneous injection of $1 \mathrm{mg} / \mathrm{kg}$ D-methamphetamine (METH)-HCl (free base) in saline to yield an injection volume of $5 \mathrm{ml} / \mathrm{kg}$ body weight; activity was recorded for an additional $2 \mathrm{hr}$ at $3 \mathrm{~min}$ intervals. Recording was done during the light cycle. Horizontal activity and total distance moved (in centimeters) were measured, as were regional movements (center vs periphery).

Morris maze. On P50 all animals within a litter were administered four timed trials in a $15 \times 244 \mathrm{~cm}$ straight water channel with a wire ladder at one end. The channel was constructed of PVC material and filled with $27-29^{\circ} \mathrm{C}$ water to a depth of $35 \mathrm{~cm}$. Subjects were placed in the channel at the opposite end from the ladder and given a maximum of $60 \mathrm{sec}$ to find the ladder and escape. These trials were used to measure swimming proficiency and motivation to escape from water before the Morris water maze trials. Two litters of mice were excluded from further behavioral testing because of failure to swim after repeated placements in the water.

The Morris water maze was used with modifications for mice (Upchurch and Wehner, 1988). The maze was a circular stainless steel perimeter $122 \mathrm{~cm}$ in diameter that was surrounded by an outer tank 162 $\mathrm{cm}$ in diameter. The inner perimeter was covered with flat white paint. The clear acrylic platform was $10 \times 10 \mathrm{~cm}$ and submerged $1 \mathrm{~cm}$ below the surface of the water. White tempera paint was added to the water to camouflage the platform. Water temperature was maintained at $27-29^{\circ} \mathrm{C}$. Litters were divided into two groups to balance for platform position. Testing began on P51 and continued for $18 \mathrm{~d}$, with $6 \mathrm{~d}$ each for hidden platform acquisition and reversal (with the platform moved to the opposite quadrant), followed by cued learning. For hidden platform acquisition the platform was placed in the SE or NW quadrant; start positions $(\mathrm{N}, \mathrm{S}, \mathrm{E}$, and $\mathrm{W})$ were altered on every trial in a quasi-random sequence such that each cardinal position was used only once per day. Four trials were given each day with a maximum time limit of 1 min and intertrial intervals of $30 \mathrm{sec}$. Mice not finding the platform in $1 \mathrm{~min}$ were placed on the platform for the $30 \mathrm{sec}$ intertrial interval. Probe trials $(1 \mathrm{~min})$ were given on day 3 before the acquisition trials and day 6 after the last acquisition trial with the platform removed; probe trials were begun from novel start locations. For the reversal phase the same procedure was followed with the platform shifted to the opposite quadrant. Probe trials for mice tested with the NW platform site for reversal were not used for 
statistical analysis because of a procedural error. For cued learning, black curtains were drawn around the maze to obscure distal cues, and the platform was marked by using a black solid cylinder $(5 \times 7 \mathrm{~cm})$ mounted on a $14 \mathrm{~cm}$ brass rod above the platform. Four trials per day were given, with the platform and start positions randomly located for each trial. Mice were placed in a holding cage for the $30 \mathrm{sec}$ intertrial interval while the platform was positioned for the next trial. Data were recorded for acquisition and reversal phases with a video tracking system (San Diego Instruments, San Diego, CA). Cued acquisition latencies were recorded with a hand-held timer and observed on a closed circuit monitor.

Preparation and treatment of neostriatal slices. Male $\mathrm{PDE}^{-1-}$ and WT mice (8-12 weeks of age) were decapitated. The brain was transferred rapidly to an ice-cold surface, blocked, and fixed to the cutting surface of a Vibratome (Ted Pella, Redding, CA) maintained at $4^{\circ} \mathrm{C}$. The brain was submersed in cold, oxygenated $\left(95 \% \mathrm{O}_{2} / 5 \% \mathrm{CO}_{2}\right)$ Krebs' bicarbonate buffer of the following composition (in $\mathrm{mM}$ ): $125 \mathrm{NaCl}, 5$ $\mathrm{KCl}, 26 \mathrm{NaHCO}_{3}, 1.5 \mathrm{CaCl}_{2}, 1.5 \mathrm{MgSO}_{4}$, and 10 glucose, $\mathrm{pH}$ 7.4. Coronal mouse brain sections ( $400 \mu \mathrm{m}$ in thickness) were cut and pooled in cold buffer. Striatal or nucleus accumbens slices were cut from the coronal sections under a dissecting microscope. Individual slices were preincubated in fresh buffer for $15 \mathrm{~min}$ at $30^{\circ} \mathrm{C}$; the buffer was replaced, and preincubation continued for an additional $30 \mathrm{~min}$. At the end of this second preincubation period the buffer was replaced with Krebs' buffer or buffer containing test substances for $5 \mathrm{~min}$. Slices were frozen immediately in liquid nitrogen and stored at $-80^{\circ} \mathrm{C}$ until assayed.

Immunoblotting for phospho-DARPP-32 and phospho-GluR1. Frozen tissue samples were sonicated in $1 \%$ SDS. Small aliquots of the homogenate were retained for protein determination by the BCA protein assay method (Pierce, Rockford, IL), using bovine serum albumin as a standard. Equal amounts of protein $(50 \mu \mathrm{g})$ were loaded onto $10 \%$ acrylamide gels, separated by SDS/PAGE (Laemmli, 1970), and transferred to nitrocellulose membranes $(0.2 \mu \mathrm{m}$; Schleicher \& Schuell, Keene, NH) by the method of Towbin et al. (1979). Membranes were immunoblotted with the following antibodies: an antiserum detecting the $\mathrm{Ser}^{845}$ phosphorylated form of GluR1 (Kameyama et al., 1998); an antiserum (PharMingen, San Diego, CA) detecting the C-terminal region of GluR1, irrespective of phosphorylation state; mAb 23 (Snyder et al., 1992), a phosphorylation state-specific monoclonal antibody detecting a DARPP-32 peptide containing phospho-Thr ${ }^{34}$, the site phosphorylated by PKA; or C24-5a, a monoclonal antibody detecting DARPP-32 irrespective of phosphorylation state (Hemmings and Greengard, 1986).

Antibody binding was revealed by incubation with either a goat antirabbit horseradish peroxidase-linked IgG or a goat anti-mouse horseradish peroxidase-linked IgG (Pierce) and the enhanced chemiluminescence (ECL) immunoblotting detection system (Amersham Biosciences, Arlington Heights, IL). Chemiluminescence was detected by autoradiography with DuPont NEN autoradiography film (Boston, MA), and bands were quantified by analysis of scanned images by NIH 1.52 Image software (Bethesda, MD). Because the linear range for quantitation of ECL signals by densitometry is limited, several film exposures were obtained for each set of samples to insure that the signals were within a density range that allowed for accurate quantitation.

Statistical methods. Data were analyzed via ANOVA (general linear model). For data that had repeated measure components, split plot ANOVAs were used, with day and trial treated as within-subject factors in the analyses (Kirk, 1995). Data were averaged within a litter for each genotype having more than one subject of the same gender (Holson and Pearce, 1992). Significant interactions were analyzed further by using simple-effect ANOVA. A posteriori group comparisons were performed by the method of Duncan. Analyses for time-dependent interactions were performed on activity data, using trend analyses by orthogonal decomposition. $\chi^{2}$ was used to analyze whether the proportion of mice of each genotype matched predicted Mendelian ratios. Neostriatal slice data were analyzed by a Mann-Whitney $U$ test, as indicated, with significance defined as $p<0.05$.

\section{RESULTS}

\section{Generation of PDE1B-deficient mice}

To generate mice deficient in PDE1B activity, we constructed a targeting vector to disrupt the sequences encoding the PDE1B catalytic domain in mouse ES cell genomic DNA by homologous recombination (Fig. 1A). Of the 302 ES cell colonies that survived HAT and Cytovene selection, 26 were analyzed by South-
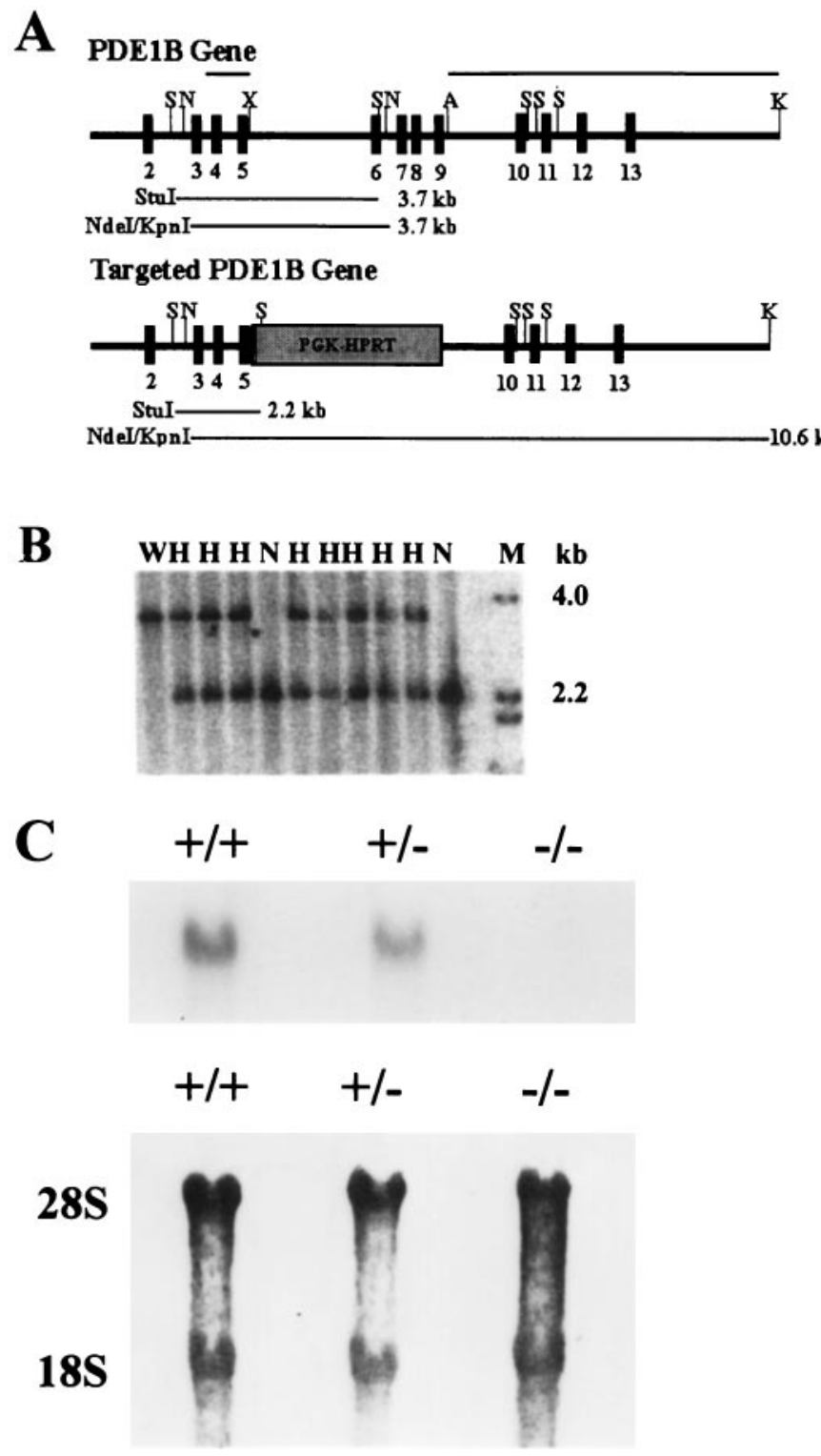

Figure 1. Targeting strategy for PDE1B and Southern and Northern blot analysis of offspring of the third generation backcrossing. $A$, Schematic of a portion of the endogenous PDE1B gene and the result of homologous recombination with the targeting vector. A $3.1 \mathrm{~kb}$ portion of the PDE1B gene encoding the central catalytic domain was disrupted by replacement with the $2.9 \mathrm{~kb}$ HPRT gene. Disruption resulted in a size shift in the $S t u \mathrm{I}$ fragment from 3.7 to $2.2 \mathrm{~kb}$ and a size shift in an NdeI/KpnI fragment from 3.7 to $10.6 \mathrm{~kb}$. The bars above the PDE1B gene represent genomic DNA sequences included in the targeting vector. The bars below the PDE1B gene indicate the restriction fragments used for Southern blot analysis of ES cell and mouse genomic DNA. Numbered thick vertical lines represent exons. Thin vertical lines indicate restriction enzyme sites. S, StuI; N, NdeI; X, $X b a \mathrm{I} ; A, A c c \mathrm{I} ; K, K p n \mathrm{I}$. B, Southern blot of offspring of third generation backcross mice of mouse genomic DNA digested with StuI demonstrating wild-type $(W)$, heterozygous $(H)$, and null $(N)$ genotypes. The $2.2 \mathrm{~kb} S t u \mathrm{I}$ fragment was generated by homologous recombination with the targeting vector. All blots were probed with a PDE1B exon 3 probe. $C$, Brain total RNA from mice of each genotype was analyzed by Northern blot by hybridizing with K-17, a cDNA probe corresponding to the central catalytic domain (Repaske et al., 1992). The expected $\sim 3.0 \mathrm{~kb}$ transcript is observed in the $\mathrm{WT}$ and $\mathrm{PDE} 1 \mathrm{~B}^{+/-}$mice only (top). The methylene blue-stained ribosomal bands on the same Northern blot demonstrate equal RNA loading (bottom). 
ern blot with a probe corresponding to PDE1B exon 3 and flanking intron sequence. The disrupted gene was present in nine of these clones (data not shown).

Two recombinant ES cell lines were microinjected into embryonic day 3.5 (E3.5) C57BL/6 blastocysts and implanted in pseudopregnant females. Twenty-eight chimeras were generated (17 males and 11 females); eight $(29 \%)$ from one ES cell line demonstrated germline transmission when bred to $\mathrm{C} 57 \mathrm{BL} / 6$ mice. Third backcross PDE1B ${ }^{+/-}$mice were interbred, resulting in 178 wild-type (WT; 27\%), $309 \mathrm{PDE}^{+/-}(47 \%)$, and 157 PDE1B $^{-1-}(24 \%)$ mice and 13 mice that died before being genotyped $(2 \%)$. These proportions did not differ significantly from the expected Mendelian ratio of $1: 2: 1$ by $\chi^{2}$ analysis. A Southern blot demonstrating $\mathrm{F}_{4}$ genotypes is shown in Figure $1 B$.

The physical appearance and general behavior of PDE1B ${ }^{-1-}$ and PDE1B ${ }^{+/-}$mice were identical to those of their WT littermates. There were no significant differences in either preweaning or postweaning weights among the three genotypes. There was a small, but significant, increase in the number of PDE1B ${ }^{-/-}(6 \%)$ and PDE1B ${ }^{+/-}(6 \%)$ mice that died within 1 week after birth compared with WT mice (2\%), as determined by Fisher's test for uncorrelated proportions. A Northern blot of total brain RNA probed with K-17, a 348 bp mouse partial PDE1B cDNA within the targeted domain (Repaske et al., 1992), demonstrated a reduction in PDE1B mRNA in the heterozygote and the absence of PDE1B mRNA in the null (Fig. 1C).

To characterize the phenotype of the PDE1B ${ }^{-1-}$ mice, we performed a series of tests designed to assess functions known to be associated with the brain regions in which PDE1B is expressed most abundantly. These were locomotor activity and DARPP-32 phosphorylation for striatal function, spatial learning for dentate gyrus function, and olfactory orientation for olfaction.

\section{Locomotor activity}

We studied both exploratory and D-METH stimulated activity in the PDE1B ${ }^{-/-}, \mathrm{PDE}_{\mathrm{B}}{ }^{+/-}$, and WT mice. A significant main effect of genotype was observed on horizontal locomotor activity for both the $60 \mathrm{~min}$ prechallenge exploratory activity $(p<$ 0.0003 ) and 120 min postchallenge ( $p<0.0001$ ) periods (Fig. 2). Furthermore, a significant genotype by interval interaction was observed for both prechallenge $(p<0.03)$ and postchallenge $(p<0.0001)$ horizontal activity. Simple-effect ANOVAs and post hoc tests showed that prechallenge PDE1B ${ }^{+/-}$locomotor activity was comparable with that of WT mice (Fig. 2). However, $\mathrm{PDE}_{\mathrm{B}}{ }^{-/-}$mice explored more, especially during the first 30 min. From 30 to 60 min the PDE1B ${ }^{-/-}$mice habituated toward WT levels but remained slightly more active. Simple-effect ANOVAs and post hoc group comparisons on post-METH challenge horizontal activity showed that the $\mathrm{PDE}_{\mathrm{B}}{ }^{+/-}$mice were not significantly more active than WT mice. PDE1B ${ }^{-1-}$ mice, on the other hand, were significantly more active than WT mice. The hyperactivity lasted for $\sim 90$ min after METH treatment.

To determine whether the stimulated response of the PDE1B ${ }^{-/-}$mice was qualitatively as well as quantitatively different from that of WT mice, we used trend analysis, using orthogonal decomposition. PDE1B ${ }^{-1-}$ to WT comparisons showed significant linear, quadratic, and cubic trends for the genotype by interval interaction $(p<0.03)$, whereas the $\mathrm{PDE}^{\mathrm{B}} \mathrm{B}^{+/-}$to $\mathrm{WT}$ interactions showed no significant differences. In the PDE1B ${ }^{-/-}$ to WT comparison, the quadratic trend best fit the data, revealing that the PDE1B ${ }^{-/-}$mice not only were more active but also had a larger rate of change (greater slope) than the WT mice in

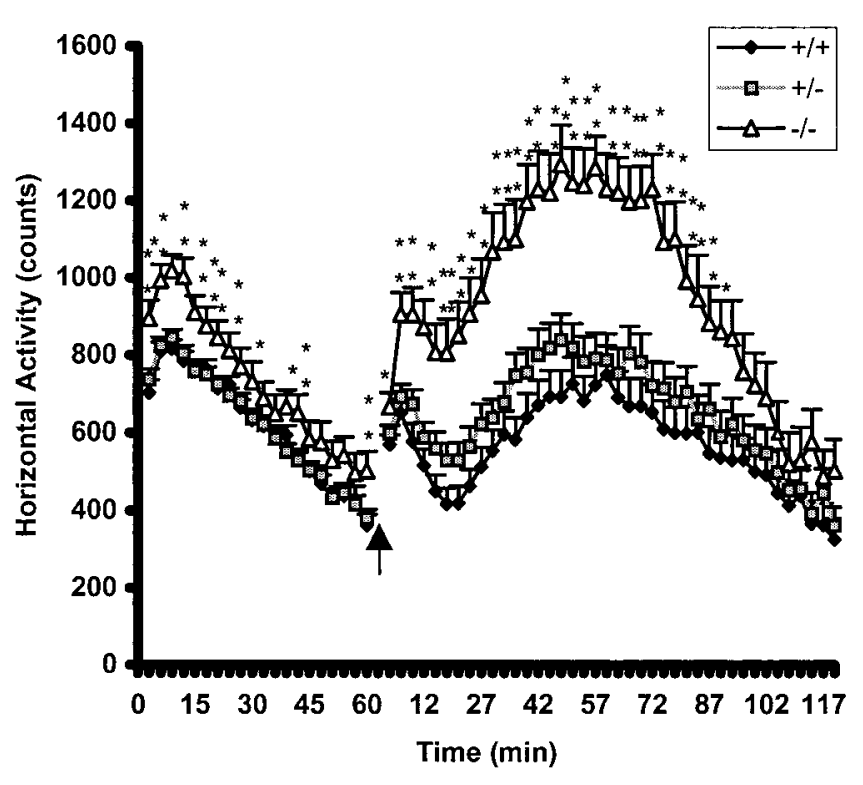

Figure 2. Horizontal activity. Shown is the mean \pm SEM horizontal activity for PDE1B ${ }^{-1-}, \mathrm{PDE}^{+/-}$, and WT mice (males and females combined). An arrow indicates the time of methamphetamine administration $(1 \mathrm{mg} / \mathrm{kg})$. Counts represent the total number of photo beam interruptions per 3 min interval. PDE1B ${ }^{-1-}$ mice were hyperactive compared with WT mice both before $\left(F_{(2,120)}=8.55 ; p<0.0003\right)$ and after $\left(F_{(2,120)}=11.18 ; p<0.0001\right)$ methamphetamine challenge. ${ }^{*} p<0.05$; $* * p<0.01 . n=+/+, 71 ;+/-, 114 ;-/-, 49$.

response to METH. This can be seen in Figure 2 by the sharper rise in activity over the same time period in $\mathrm{PDE}_{1 \mathrm{~B}}{ }^{-/-}$mice after METH than occurred in WT mice.

The related measure of total distance followed the same pattern as horizontal activity. As with horizontal activity, there was a significant main effect of genotype both prechallenge $(p<$ $0.001)$ and postchallenge $(p<0.0002)$. PDE1B ${ }^{-/-}$mice traveled greater distances compared with WT mice in the prechallenge $(p<0.004)$ and postchallenge periods $(p<0.0002$; data not shown). A genotype by interval interaction also was observed for both prechallenge $(p<0.0001)$ and postchallenge $(p<0.0001)$, and the pattern was comparable with that seen for horizontal activity. One difference was that a genotype by sex interaction was obtained during the prechallenge period $(p<0.05)$. As can be seen in Figure 3, PDE1B ${ }^{-/-}$females accounted for this effect on total distance; males showed no pre-METH differences. After METH challenge both PDE1B ${ }^{-/-}$males and females showed greater stimulated hyperactivity than WT mice. PDE1B ${ }^{+/-}$ males showed an intermediate response to METH, suggesting a gene-dosage effect. Analyses of regional changes in activity showed the same significant main effects and interactions as seen with total distance.

\section{Phosphorylation of PKA substrates in PDE1B ${ }^{-1-}$ mice}

Based on the locomotor activity differences in $\mathrm{PDE}^{-1 \mathrm{~B}^{-/}}$mice that used the indirect dopamine agonist methamphetamine, we investigated the possibility that these mice would exhibit enhanced protein phosphorylation in response to activation of adenylyl cyclase. Forskolin $(10 \mu \mathrm{M})$, a direct activator of adenylyl cyclase, was used to increase cAMP levels in striatal slices from WT and PDE1B ${ }^{-1-}$ mice (Fig. 4A). Forskolin treatment induced a significantly greater fold increase in levels of phospho-Thr ${ }^{34}$ DARPP-32 in striatal slices from PDE1B ${ }^{-1-}$ mice $(65.7 \pm 20$-fold 

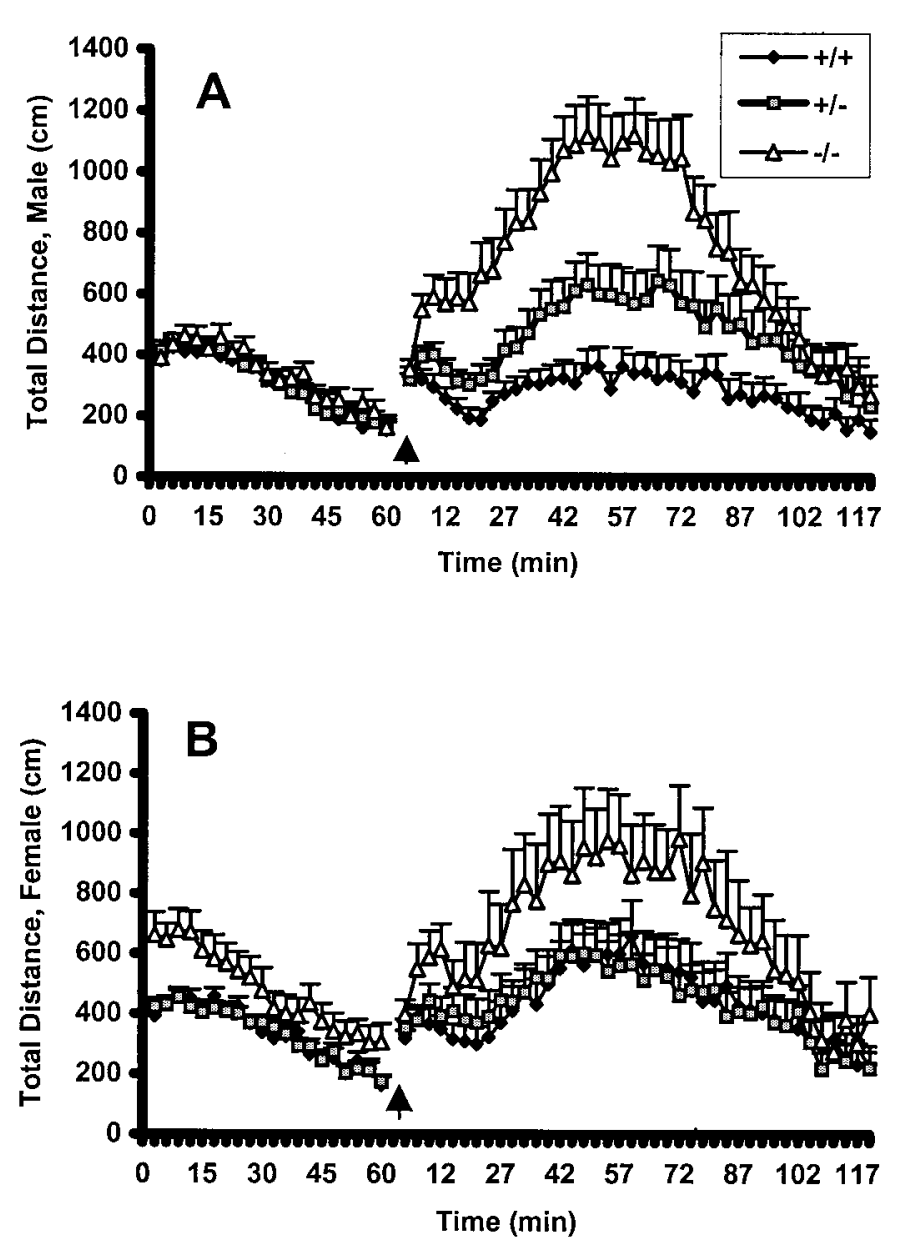

Figure 3. Sex differences in total distance. Shown is the mean \pm SEM distance traveled by males (top) and females (bottom) in the activity apparatus in 3 min blocks. The arrow indicates time of methamphetamine administration $(1 \mathrm{mg} / \mathrm{kg})$. Female $\mathrm{PDE} \mathrm{B}^{-/-}$mice, but not male $\mathrm{PDE}_{\mathrm{B}}{ }^{-1-}$ mice, were hyperactive compared with WT mice during the pre-methamphetamine challenge period $\left(F_{(2,120)}=3.07 ; p<0.05\right)$; this sex difference did not continue into the postchallenge period. $n=+/+$, $71 ;+/-, 114 ;-/-, 49$.

over untreated control) than from WT mice $(21.9 \pm 6$-fold over untreated control) ( $p<0.05$, null compared with WT mice) (Fig. $4 B)$. To investigate PKA-mediated protein phosphorylation further, we used a dopamine agonist. Striatal slices prepared from male WT and PDE1B ${ }^{-/-}$mice were treated with the selective agonist of dopamine D1-type receptors, SKF81297 (10 $\mu \mathrm{M})$, for $10 \mathrm{~min}$. The effect of this treatment on phosphorylation of DARPP-32 at $\mathrm{Thr}^{34}$ and the GluR1 AMPA receptor at Ser ${ }^{845}$, two substrates regulated via activation of D1 receptors and PKA (Greengard et al., 1999), was measured by using phosphorylation state-specific antibodies (Fig. 4C,D). In striatal slices from WT mice, D1 agonist treatment increased the levels of phospho-Thr ${ }^{34}$ DARPP-32 by $4.7 \pm 2.3$-fold and phospho-Ser ${ }^{845}$ GluR1 by $4.4 \pm$ 0.8 -fold (Fig. $4 D$ ). In contrast, in striatal slices from PDE1B ${ }^{-/-}$ mice, there were significantly greater increases in levels of both phospho-Thr ${ }^{34}$ (15.8 \pm 5 -fold over control) and phospho-Ser ${ }^{845}$ (13.1 \pm 3.2-fold over control) (Fig. 4D) ( $p<0.05$; MannWhitney $U$ test). An enhanced D1-mediated phosphorylation at both $\mathrm{Thr}^{34}$ and Ser ${ }^{845}$ also was observed in nucleus accumbens slices from $\mathrm{PDE}^{-1-}$ compared with WT mice (data not shown). No significant difference was detected in basal levels of
phospho-Thr ${ }^{34}$ or phospho-Ser ${ }^{845}$ or in total levels of DARPP-32 or GluR1 in untreated striatal (Fig. $4 C$ ) or accumbens (data not shown) slices from WT and PDE1B ${ }^{-1-}$ mice.

\section{Olfactory orientation}

No significant differences were found among the three genotypes in olfactory orientation scores (data not shown).

\section{Learning and memory}

In straight channel trials no significant differences were found among the three genotypes, thereby demonstrating equal swimming ability and motivation to escape (data not shown). Similarly, there were no main effects or interactions found for cued learning when proximal cues were present and distal cues were removed from the Morris water maze (data not shown).

In acquisition of a hidden platform in the Morris water maze, both $\mathrm{PDE}_{1 \mathrm{~B}}{ }^{+-}$and PDE1B ${ }^{-/-}$mice had significantly longer path length than WT mice (group main effect; $p<0.0002$ ) (Fig. $5 A$ ). A significant day by genotype by platform interaction also was found $(p<0.04)$. Although WT mice tested with the platform in both quadrants had shorter path lengths than PDE1B ${ }^{+/-}$ or PDE1B ${ }^{-1-}$ mice, the interaction occurred because the effect was larger on days 3-6 with the platform in the SE quadrant. A significant trial by genotype by sex effect on path length was found also; the contribution of gender was small and not instructive.

The same pattern was observed for cumulative distance from target during acquisition (Fig. $5 B$ ). Cumulative distance from the target measures the animal's distance from the platform every 55 msec. PDE1B ${ }^{+/-}$and PDE1B ${ }^{-/-}$mice had significantly longer cumulative distances than WT mice (group main effect; $p<$ $0.0004)$. A significant day by genotype by platform interaction $(p<0.05)$ was found in which WT to PDE1B ${ }^{-/-}$and PDE1B ${ }^{+/-}$ comparisons were again largest on days 3-6 for the SE quadrant. In addition, a trial by genotype by sex interaction $(p<0.01)$ was observed on this measure. As before, the gender contribution was minor.

For latency an almost identical pattern was seen (data not shown). As with the other measures, the effect was larger for one goal quadrant than the other (SE). PDE1B ${ }^{-/-}$and PDE1B ${ }^{+/-}$ mice had significantly longer latencies than WT mice on days 3 $(p<0.03)$ and $4(p<0.01)$, respectively. A trial by genotype by sex interaction $(p<0.004)$ was found, and as before the contribution of sex was minor.

Learning curves for path length are shown in Figure 6. The patterns for cumulative distance and latency were comparable with those for path length. As can be seen, all groups showed similar performance on day 1 , indicating that there were no preexisting performance differences among the genotypes. On subsequent days WT mice showed steady improvement, acquiring shorter paths to the goal on each successive day. PDE1B ${ }^{-/-}$and $\mathrm{PDE}_{\mathrm{B}} \mathrm{B}^{+/-}$mice, on the other hand, showed less improvement than WT mice, resulting in significant group differences on test days 3-6. Even on day 6 after 24 trials, $\mathrm{PDE}_{1 \mathrm{~B}}{ }^{-1-}$ and $\mathrm{PDE}^{+/-}$mice did not perform as well as WT mice.

Probe trial measurements of path length and time in the target zone were analyzed two ways: by annuli and quadrants. First, three annuli were defined. The target annulus was the one demarcated by the inner and outer edges of the platform, the outer annulus was from the outside boundary of the target annulus to the side-wall, and the inner annulus was from the inside boundary of the target annulus to the center. Second, probe trial data were analyzed by dividing the maze into four equal quadrants. Overall, $\mathrm{PDE}_{1 \mathrm{~B}}{ }^{-/-}$and $\mathrm{PDE} 1 \mathrm{~B}^{+/-}$mice swam significantly less in the 
A.

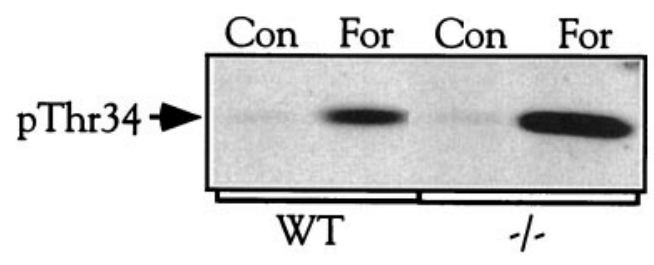

C.
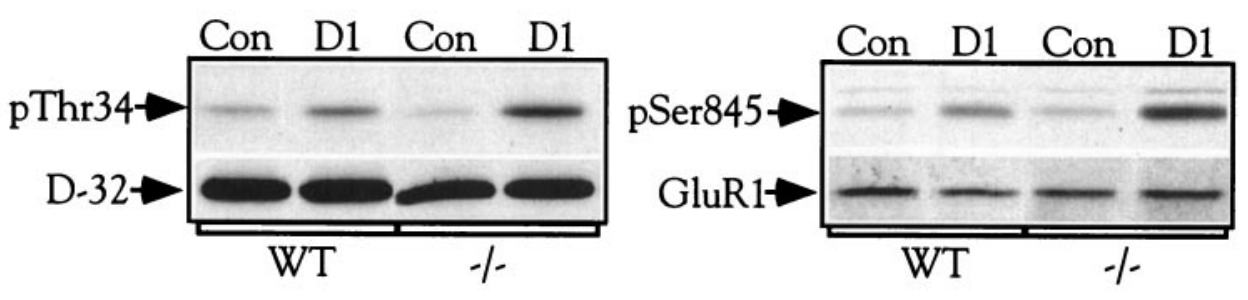

D.

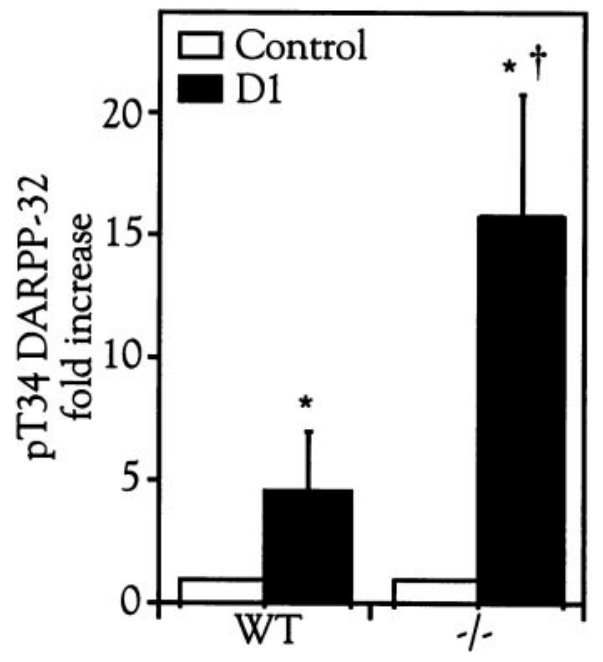

B.

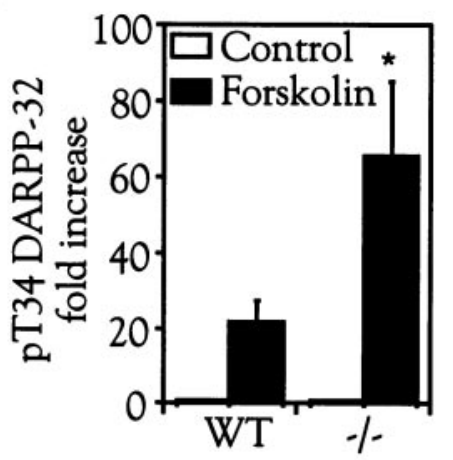

Figure 4. Phosphorylation of PKAmediated substrates in WT and $\mathrm{PDE}_{1 \mathrm{~B}}{ }^{-/-}$mice. $A$, Immunoblot showing level of phospho-Thr ${ }^{34}$-DARPP-32 in control (Con) striatal slices and in slices treated with the adenylyl cyclase activator forskolin (For) from WT and PDE1B $^{-1-}$ mice. $B$, Fold increase in phospho-Thr ${ }^{34}$-DARPP-32 in response to forskolin $\left({ }^{*} p<0.05\right.$ compared with WT forskolin; Mann-Whitney $U$ test; $n=3$ mice per treatment group). $C$, Immunoblot showing levels of phospho$\mathrm{Thr}^{34}$ and total DARPP-32 (left) and phospho-Ser ${ }^{845}$ and total GluR1 (right) in untreated (Con) and D1-agonisttreated $(D 1)$ striatal slices from WT and PDE1B $^{-1-}$ mice. $D$, Mean \pm SEM increase in the levels of phospho- $\mathrm{Thr}^{34}$ DARPP-32 (left) and phospho-Ser ${ }^{845}$ GluR1 (right) on incubation with D1 agonist $\left({ }^{*} p<0.05\right.$ compared with untreated control slices; ${ }^{\dagger} p<0.05 \mathrm{com}$ pared with D1-treated WT slices; Mann-Whitney $U$ test; $n=3$ mice per treatment group). target annulus than WT mice $(p<0.04)$ (Fig. 7A). A significant genotype by platform position interaction was found in both the target annulus $(p<0.04)$ and the outer annulus $(p<0.05)$. $\mathrm{PDE}_{1 \mathrm{~B}}{ }^{-/-}$and PDE1B ${ }^{+/-}$mice swam less in the target annulus than WT mice, especially those tested with the platform in the SE quadrant $(p<0.01)$. Conversely, $\mathrm{PDE}_{\mathrm{B}}{ }^{-/-}$and $\mathrm{PDE}_{\mathrm{B}}{ }^{+/-}$ mice swam significantly more in the outer annulus than WT mice $(p<0.01)$ (Fig. 7B). No significant difference was found in path length or time within the inner annulus or in platform site crossings. A significant interaction of day by genotype by platform position $(p<0.01$ ) was found for average distance from the target in which $\mathrm{PDE} 1 \mathrm{~B}^{+/-}$mice were significantly farther from the target site than WT mice $(p<0.007)$. No differences in time or distance in the target quadrant were found.

For reversal testing, no significant differences were found for the measures of path length or cumulative distance. A trial by genotype interaction $(p<0.003)$ was observed for latency in which the $\mathrm{PDE} 1 \mathrm{~B}^{-/-}$mice had significantly longer latencies than
WT mice on the last trial of each day $(p<0.01)$. No significant differences were found on reversal probe trials.

\section{DISCUSSION}

We generated mice deficient in PDE1B by disruption of the portion of the PDE1B gene that encodes the central catalytic domain (Fig. 1). PDE1B mRNA is undetectable in the $\mathrm{PDE}_{\mathrm{B}}{ }^{-1-}$ mouse, and there was no apparent upregulation of the normal allele in the PDE1B ${ }^{+/-}$mouse (Fig. $1 C$ ). We have demonstrated that mice lacking PDE1B activity have significantly increased spontaneous and $\mathrm{METH}$-induced locomotor activity compared with WT and PDE1B ${ }^{+/-}$mice. PDE1B ${ }^{-/-}$mice have alterations in behavior that are likely a consequence of the disruption of striatal pathways involved in the regulation of locomotor activity as demonstrated by the changes in phosphorylation levels of DARPP-32 and GluR1. PDE1B ${ }^{-1-}$ mice are hyperactive in comparison to $\mathrm{WT}$ and $\mathrm{PDE} 1 \mathrm{~B}^{+/-}$mice measured as either horizontal activity (Fig. 2) or total distance (Fig. 3). These 

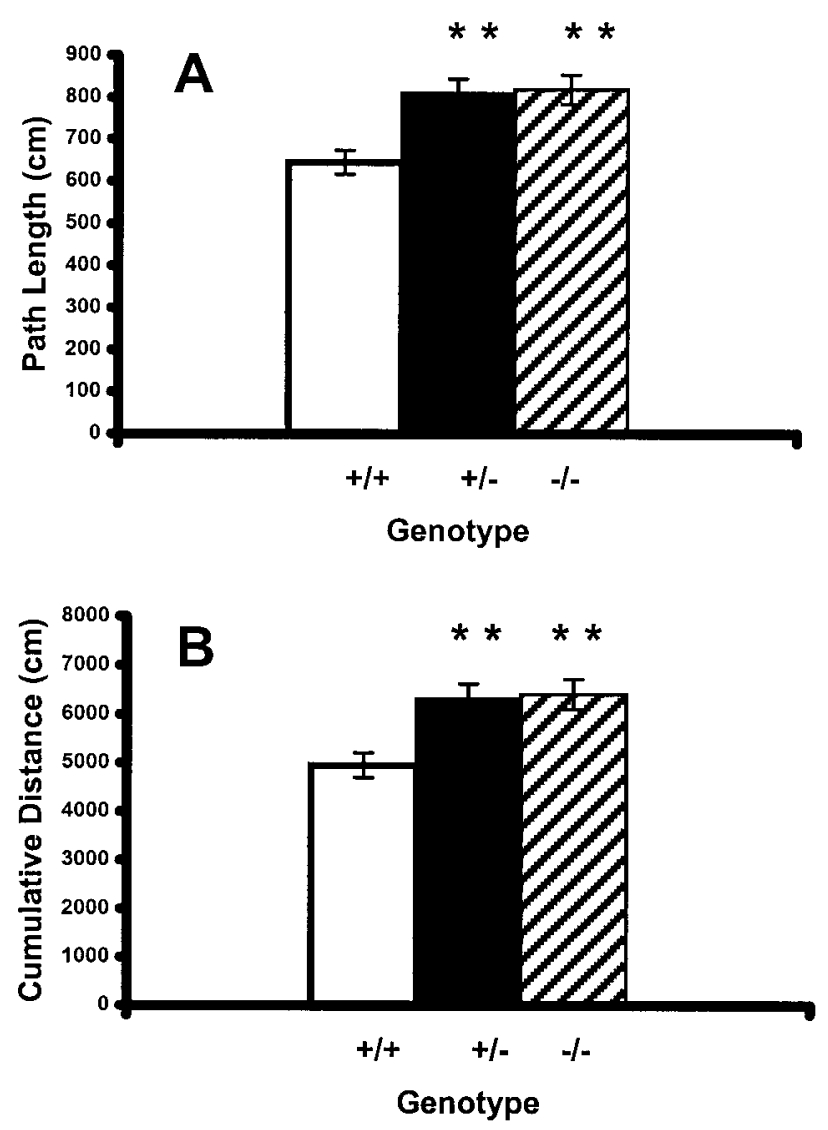

Figure 5. Spatial learning in the Morris water maze. A, Path length (mean \pm SEM) to reach the platform for mice of each genotype. $\mathrm{PDE}_{\mathrm{B}}{ }^{-/-}$and $\mathrm{PDE} 1 \mathrm{~B}^{+/-}$mice showed significantly increased path length compared with WT mice $\left(F_{(2,112)}=9.19 ; p<0.0002\right)$. B, Cumulative distance from the platform (mean \pm SEM) for mice of each genotype. PDE1B ${ }^{-1-}$ and $\mathrm{PDE} 1 \mathrm{~B}^{+/-}$mice showed a significantly increased cumulative distance compared with WT mice $\left(F_{(2,112)}=8.38 ; p<\right.$ $0.0004)$. Data are shown for the average of four trials per day averaged across all 6 d. ${ }^{* *} p<0.01$ compared with wild-type mice. $n=+/+, 55$; $+/-, 101 ;-/-, 66$.

changes occurred in response to a novel environment (initial exploration) and in a more pronounced manner in response to METH challenge. However, the METH-induced response was distinct, as indicated by the fact that the exploratory differences had dissipated in large part by the time the METH was administered. The postchallenge interval was characterized by two phases of response. The first phase preceded the onset of effects of METH (first 9 min) when the PDE1B ${ }^{-/-}$mice showed a larger rise in activity than WT, showing that even handling and injection induced a greater response in $\mathrm{PDE}_{1 \mathrm{~B}}{ }^{-/-}$mice than in $\mathrm{WT}$ mice. Then activity decreased in all groups, followed by a large increase beginning $\sim 24$ min after injection. The $\mathrm{PDE}_{1 \mathrm{~B}}{ }^{-1-}$ mice were already more active by this time. As the METH effect increased, the $\mathrm{PDE}^{-1-}$ mice responded with larger increases in activity than WT or PDE ${ }^{+/-}$mice. Although not quantified, no signs of stereotypy were noted among any of the three genotypes. However, with higher doses of METH, a shift to stereotypy would be expected, accompanied by a reduction in horizontal locomotion. It is worth noting that the present experiment did not include groups challenged with saline after the first hour to assess the locomotor habituation that would be expected during hours $2-3$ of testing. Such controls will be needed in future experiments

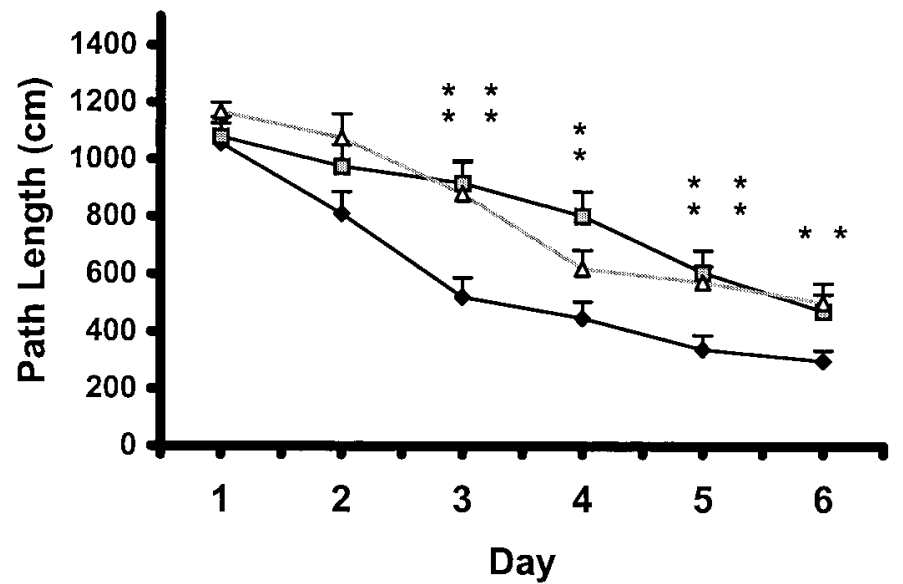

Figure 6. Spatial learning in the Morris water maze: acquisition of hidden platform task. Data are shown for the average of four trials per day for each of the three genotypes. PDE1B ${ }^{-/}$and PDE1B ${ }^{+/-}$mice showed significantly increased path length compared with WT mice on days 3-6 (genotype by day by platform interaction; $F_{(10,560)}=2.01 ; p<0.04$ ). * $p<$ 0.05 and $* * p<0.01$ compared with WT mice. Filled diamonds, $+/+(n=$ $55)$; shaded squares, $+/-(n=101)$; open triangles, $-/-(n=66)$.

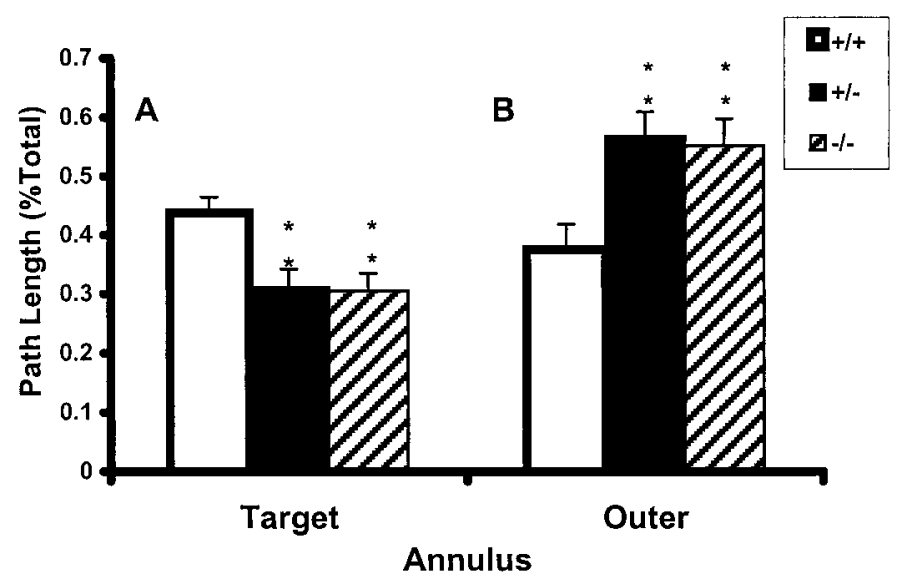

Figure 7. Spatial memory in the Morris water maze: probe trial performance. Path length (mean \pm SEM) is expressed as a percentage of total swim time in the target annulus $(A)$ and the outer annulus $(B)$ averaged across the two probe trials and gender. ${ }^{*} p<0.01$ compared with wild-type mice.

with this model to characterize fully the response of the $\mathrm{PDE}_{\mathrm{B}}{ }^{-1-}$ mice to dopaminergic agonists.

Locomotor activity has been used extensively to test for the effects of neurotoxins and psychostimulants (Rafales, 1986). Psychostimulants such as cocaine and amphetamines have been shown to affect locomotor activity by dopaminergic pathways (Traficante et al., 1976). These substances bind to the dopamine transporter (DAT), resulting in increased extracellular DA and subsequent increased DA interaction with D1 receptors. Increased D1 receptor interactions result in activating adenylyl cyclase activity, which increases intracellular levels of cAMP (Giros et al., 1996). Increased intracellular levels of cAMP activate PKA, which phosphorylates intracellular proteins, including DARPP-32 and CREB (Cunningham and Kelley, 1993; Konradi et al., 1994; Miserendino and Nestler, 1995). DA binding to D1 receptors also increases intracellular levels of cGMP via an unknown mechanism that leads to the activation of protein kinase $G$ (PKG) and the phosphorylation of DARPP-32 and other proteins 
(Altar et al., 1990; Tsou et al., 1993). Disruptions of these pathways cause changes in levels of locomotor activity as shown in mice lacking DA, DA receptors, DAT, or DARPP-32. Mice that lack an active tyrosine hydroxylase gene, the rate-limiting enzyme in DA synthesis, or D1 receptors were hypoactive (Drago et al., 1994) even in response to cocaine (Xu et al., 1994) and exhibited decreased rearing (Zhou and Palmiter, 1995). Mice lacking D2 receptors also had reduced levels of activity and reduction in controlled motor movement (Balk et al., 1995). Conversely, mice lacking DAT demonstrated increased levels of locomotor activity that were unaltered by cocaine or METH challenge (Giros et al., 1996). DARPP-32 null mice exhibited greater sensitivity to repeated injections of cocaine but did not have significantly different levels of locomotor activity in response to acute cocaine administration (Fienberg et al., 1998; Hiroi et al., 1999).

$\mathrm{PDE} \mathrm{B}^{-/-}$mice demonstrated increased levels of activity in comparison with WT mice and even greater increases in activity with an acute METH challenge. Removing PDE1B cyclic nucleotide-hydrolyzing ability presumably increased the magnitude and prolonged the duration of the D1 receptor-generated increase in cyclic nucleotides and their downstream phosphorylation signaling. Therefore, although we found increased activity as seen in the DAT-knock-out mice (Giros et al., 1996), the effect in PDE1B ${ }^{-1-}$ mice was mediated postsynaptically rather than presynaptically as in the DAT-KO mouse. Our mice differed dramatically from DAT-KO mice in response to sympathomimetic challenge, in that DAT-KO mice show blunted responses to stimulants whereas PDE1B-KO mice show exaggerated responses.

As reviewed recently (Greengard et al., 1999), the phosphorylation state of DARPP-32 plays a central role in the cellular and molecular responses within medium spiny striatal neurons. Glutamate and D2 DA receptors increase intracellular $\mathrm{Ca}^{2+}$, thereby activating calcineurin. Calcineurin dephosphorylates DARPP-32, resulting in disinhibition of protein phosphatase-1 (PP-1) (Kotter, 1994; Greengard et al., 1999). Conversely, DA D1 receptors, adenosine receptors, and nitric oxide (NO) pathways increase intracellular cyclic nucleotide concentrations that activate PKA and PKG to phosphorylate DARPP-32 and promote the inhibition of PP-1, thereby having the reverse effect (Greengard et al., 1999). PP-1 regulates the activity of neurotransmitter receptors and voltage-gated ion channels, thereby affecting striatal synaptic transmission (Surmeier et al., 1995; Yan and Surmeier, 1997; Snyder et al., 1998). PDE1B lowers intracellular levels of cAMP and cGMP by hydrolyzing them in response to $\mathrm{Ca}^{2+}$ activation (Krinks et al., 1984; Erneux et al., 1985), thus terminating the signaling cascade. The present study provides evidence that PDE1B is a regulator of the phosphorylation state of DARPP-32 (Fig. 4).

Spatial learning deficits in $\mathrm{PDE}_{1} \mathrm{~B}^{-/-}$and $\mathrm{PDE}^{+/-}$mice were seen also. The effect was comparable in $\mathrm{PDE}^{-1-}$ mice that had no detectable PDE1B and in PDE1B ${ }^{+/-}$mice that had $\sim 50 \%$ of the normal adult PDE1B level (Figs. 5, 6). PDE1B ${ }^{+/-}$ and $\mathrm{PDE} 1 \mathrm{~B}^{-/-}$mice swam greater distances to reach the platform than WT mice and were further away from the platform on average than WT mice, suggesting that they used a less efficient search strategy. This is supported by the probe trial data in that $\mathrm{PDE}_{1 \mathrm{~B}}^{+/-}$and PDE1B ${ }^{-/-}$mice swam less than WT mice in the target annulus and more in the outer annulus (Fig. 7). Decreases in target annulus swimming combined with increases in outer annulus swimming have been shown to reflect impaired spatial ability in rats (Saucier et al., 1996). Learning differences among genotypes were not attributable to visual impairments or motivational deficits, because performances in the straight channel and cued platform version of the maze were not different among the groups.

It has been shown previously that rats with striatal lesions are impaired in Morris maze spatial learning (D'Hooge and De Deyn, 2001). Therefore, it is possible that the impaired Morris maze learning seen in PDE1B ${ }^{-/-}$and PDE1B ${ }^{+/-}$mice may be the result of the striatal phenotype of these mice. Alternatively, the Morris maze deficits could be the result of the deficiency of PDE1B function in the dentate gyrus, the other area of high expression of this enzyme and an area closely associated with spatial learning (D'Hooge and De Deyn, 2001). A third possibility is that the Morris maze deficits could be the product of the dual effect of PDE1B disruption in the striatum and the dentate gyrus. These dual neuroanatomical substrates for learning might explain why both $\mathrm{PDE}_{1 \mathrm{~B}}^{-/-}$and $\mathrm{PDE} 1 \mathrm{~B}^{+/-}$mice were affected in the Morris maze, but only $\mathrm{PDE}_{1 \mathrm{~B}}{ }^{-/-}$mice were affected on locomotion inasmuch as locomotion has only one region of PDE1B involvement compared with at least two regions for spatial learning.

The dual region effect also may explain why $\mathrm{PDE} \mathrm{B}^{-/-}$and $\mathrm{PDE}_{1 \mathrm{~B}}{ }^{+/-}$mice are not entirely the same as animals with striatal lesions in terms of Morris maze performance. Rats with striatal lesions (especially dorsomedial lesions) exhibit increased thigmotaxis (Devan et al., 1996, 1999; Devan and White, 1999; D'Hooge and De Deyn, 2001) reminiscent of the pattern seen here in mice with disrupted PDE1B function on probe trials. However, some studies find that rats with striatal lesions exhibit increased thigmotaxis only on early acquisition trials and on probe trials (Devan et al., 1996, 1999; Devan and White, 1999). Rats with striatal lesions also are reported to be impaired on cued learning (Devan et al., 1996, 1999; Devan and White, 1999), whereas mice with disrupted PDE1B are not. However, rats with quinolinateinduced medial striatal lesions show impaired spatial acquisition in the Morris maze in the absence of changes in cued learning (Furtado and Mazurek, 1996). Taken together, these findings suggest that the combined disruption of PDE1B function in the striatum and dentate gyrus best accounts for the Morris water maze learning and memory deficits seen in our mice.

An alternative explanation for why the $\mathrm{PDE}^{-1}{ }^{-/}$and $\mathrm{PDE}_{1 \mathrm{~B}}{ }^{+/-}$mice differ in the pattern of phenotypic changes between the tests of locomotor activity and learning may arise from the influence of other PDEs. For example, expression of $\mathrm{PDE} 1 \mathrm{C}$ in the striatum may have sufficient reserve capacity to compensate for deletion of one allele of PDE1B in PDE1B ${ }^{+/-}$ mice and allow these mice to have locomotor responses comparable with WT mice. However, PDE1C expression has not been reported in dentate gyrus, thereby precluding compensation in PDE1B ${ }^{+/-}$mice in terms of spatial learning.

The results of these experiments support the conclusion that regulation of intracellular cyclic nucleotide concentration is important in the cellular processes that underlie learning and memory. The alterations observed in learning in $\mathrm{PDE}^{-1-}$ and $\mathrm{PDE}_{\mathrm{B}}{ }^{+/-}$mice suggest that PDE1B may be involved in these underlying cellular processes.

Changes in cyclic nucleotide regulation have resulted in learning deficits in olfactory discrimination paradigms as demonstrated by Drosophila mutants and also have resulted in deficits in spatial learning and memory as demonstrated in CREB mutant mice (Livingstone et al., 1984; Qui and Davis, 1993; Skoulakis et al., 1993; Bourtchuladze et al., 1994; Yin et al., 1994; Guzowski 
and McGaugh, 1997). Mutations in CaMKII (Bach et al., 1995; Mayford et al., 1995) and alterations in the level of expression of calcineurin (Mansuy et al., 1998) have implicated $\mathrm{Ca}^{2+}$ and $\mathrm{CaM}$ signal cascades in spatial learning and memory tasks. PDE1B regulation by both CaMKII (Skoulakis et al., 1993) and calcineurin has been demonstrated in vitro (Sharma and Wang, 1985, 1986), suggesting a possible mechanism by which the learning deficits observed in the PDE1B mutants may occur.

Studies in rodents and humans have demonstrated that CaMPDEs are expressed during periods of hippocampal synaptogenesis (Ludvig et al., 1991; Lal et al., 1999). The hippocampus has been implicated extensively in processes involved in long-term memory processing and storage (Jarrard, 1993; Zola-Morgan and Squire, 1993). Processes necessary for spatial navigation do not become functional until 1 month of age in rats, a period of time shortly after hippocampal development (Schenk, 1985). It is possible that CaM-PDEs serve a role in establishing the synaptic connections necessary for spatial navigation.

Although CaM-PDEs hydrolyze both cAMP and cGMP, in vitro studies have demonstrated a lower $K_{\mathrm{m}}$ for cGMP as substrate (Yan et al., 1995). The NO-cGMP signaling pathway also has been implicated in LTD in the dentate gyrus (Wu et al., 1998) and corticostriatal pathway (Engels et al., 1995). In both systems an inhibitor of cGMP PDEs induced LTD (Engels et al., 1995; Wu et al., 1998). More recently, $\mathrm{Ca}^{2+} / \mathrm{CaM}$ activation of NO synthase was shown to modulate CA1 synaptic potentiation through $\mathrm{NO}$ at postsynaptic sites (Ko and Kelly, 1999). CaM-PDEs may be predicted to be an intermediary between the cyclic nucleotide/NO and $\mathrm{Ca}^{2+} / \mathrm{CaM}$ signaling pathways. Indeed, PDE1B degradation of elevated cGMP levels resulting indirectly from stimulation of a $\mathrm{Ca}^{2+} / \mathrm{CaM}$-dependent $\mathrm{NO}$ synthase was observed in cytosolic fractions of crude rat brain synaptosomes (Mayer et al., 1993).

We found no significant deficit in $\mathrm{PDE}_{1 \mathrm{~B}}{ }^{-/-}$or $\mathrm{PDE}_{\mathrm{B}}{ }^{+/-}$in a test of neonatal olfactory orientation. This task is dependent on mice being able to detect the smell of their home cage bedding. Because we did not observe any differences in this task, it is possible that PDE1B does not play a direct role in early postnatal odorant orientation. However, it may be involved in other processes that were not assessed by this task such as relaying or processing of discrete odorant information to other brain regions.

\section{REFERENCES}

Abel T, Nguygen PV, Barad M, Deuel TA, Kandel ER, Bourtchuladze R (1997) Genetic demonstration of a role for PKA in the late phase of LTP, in hippocampus-based long-term memory. Cell 88:615-626.

Acuff-Smith KD, George M, Lorens SA, Vorhees CV (1992) Preliminary evidence for methamphetamine-induced behavioral and ocular effects in rat offspring following exposure during early organogenesis. Psychopharmacology 109:255-263.

Altar C, Boyar W, Kim H (1990) Discriminatory roles for D1 and D2 dopamine receptor subtypes in the in vivo control of neostriatal cyclic GMP. Eur J Pharmacol 181:17-21.

Bach ME, Hawkins RD, Osman M, Kandel ER, Mayford M (1995) Impairment of spatial but not contextual memory in CaMKII mutant mice with selective loss of hippocampal LTP in the range of the theta frequency. Cell 81:905-915.

Balk J-H, Picetti R, Salardi A, Thirlet G, Dierich A, Depaulis A, LeMeur M, Borrelli E (1995) Parkinsonian-like locomotor impairment in mice lacking dopamine D2 receptors. Nature 377:424-428.

Borisy FF, Ronnett GV, Cunningham AM, Julifs D, Beavo JA, Snyder SH (1992) Calcium/camodulin-activated phosphodiesterase expressed in olfactory receptor neurons. J Neurosci 12:915-923.

Bourtchuladze R, Frenguelli B, Blendy J, Cioffi D, Schutz G, Silva AJ (1994) Deficient long-term memory in mice with a targeted mutation of the cAMP-responsive element-binding protein. Cell 79:59-68.

Cunningham S, Kelley A (1993) Hyperactivity and sensitization to psychostimulants following cholera toxin infusion into the nucleus accumbens. J Neurosci 13:2342-2350.
Davis RL, Cherry J, Dauwalder B, Han P-L, Skoulakis E (1995) The cyclic AMP system and Drosophila learning. Mol Cell Biochem 149-150:271-278.

Devan BD, White NM (1999) Parallel information processing in the dorsal striatum: relation to hippocampal function. J Neurosci 19:2789-2798.

Devan BD, Goad EH, Petri HL (1996) Dissociation of hippocampal and striatal contributions to spatial navigation in the water maze. Neurobiol Learn Mem 66:305-323.

Devan BD, McDonald RJ, White NM (1999) Effects of medial and lateral caudate-putamen lesions on place- and cue-guided behaviors in the water maze: relation to thigmotaxis. Behav Brain Res 100:5-14.

D'Hooge R, De Deyn PP (2001) Applications of the Morris water maze in the study of learning and memory. Brain Res Rev 36:60-90.

Drago J, Gerfen C, Lachowicz J, Steiner H, Hollon T, Love P, Ooi G, Grinberg A, Lee E, Huang S, Bartlett P, Jose P, Sibley D, Westphal H (1994) Altered striatal function in a mutant mouse lacking $\mathrm{D}_{1 \mathrm{~A}}$ dopamine receptors. Proc Natl Acad Sci USA 91:12564-12568.

Engels P, Abdel'Al S, Hulley P, Lubbert H (1995) Brain distribution of four rat homologues of the Drosophila dunce cAMP phosphodiesterase. J Neurosci Res 41:169-178.

Erneux C, VanSande J, Miot F, Cochaux P, Decoster C, Dumont J (1985) A mechanism in the control of intracellular cAMP level: the activation of a calmodulin-sensitive phosphodiesterase by a rise of intracellular free calcium. Cell Endocrinol 43:123-134.

Fienberg AA, Hiroi N, Mermelstein PG, Song WJ, Snyder GL, Nishi A, Cheramy A, O'Callaghan JP, Miller DB, Cole DG, Corbett R, Haile CN, Cooper DC, Onn SP, Grace AA, Ouimet CC, White FJ, Hyman SE, Surmeier DJ, Girault J-A, et al (1998) DARPP-32: regulator of the efficacy of dopaminergic neurotransmission. Science 281:838-842.

Furtado JCS, Mazurek MF (1996) Behavioral characterization of quinolinate-induced lesions of the medial striatum: relevance for Huntington's disease. Exp Neurol 138:158-168.

Furuyama T, Iwashashi Y, Tano Y, Takagi H, Inahaki S (1994) Localization of $63 \mathrm{kDa}$ calmodulin-stimulated phosphodiesterase mRNA in the rat brain by in situ hybridization histochemistry. Mol Brain Res 26:331-336.

Gally JA, Montague PR, Reeke GNJ, Edelman GM (1990) The NO hypothesis: possible effects of a short-lived, rapidly diffusible signal in the development and function of the nervous system. Proc Natl Acad Sci USA 87:3547-3551.

Garthwaite J (1991) Glutamate, nitric oxide, and cell-cell signaling in the nervous system. Trends Neurosci 14:60-67.

Giros B, Jaber M, Jones SR, Wightman RM, Caron MG (1996) Hyperlocomotion and indifference to cocaine and amphetamine in mice lacking the dopamine transporter. Nature 379:606-612.

Greengard P, Allen PB, Nairn AC (1999) Beyond the dopamine receptor: the DARPP-32/protein phosphatase-1 cascade. Neuron 23:435-447.

Guzowski JF, McGaugh JL (1997) Antisense oligodeoxynucleotidemediated disruption of hippocampal cAMP response element binding protein levels impairs consolidation of memory for water maze training. Proc Natl Acad Sci USA 94:2693-2698.

Hemmings HC, Greengard P (1986) DARPP-32, a dopamine- and adenosine $3^{\prime}: 5^{\prime}$-monophosphate-regulated phosphoprotein: regional, tissue, and phylogenetic distribution. J Neurosci 6:1469-1481.

Hiroi N, Fienburg A, Haile C, Alburges M, Hanson G, Greengard P, Nestler E (1999) Neuronal and behavioural abnormalities in striatal function in DARPP-32 mutant mice. Eur J Neurosci 11:1114-1118.

Holson RR, Pearce B (1992) Principles and pitfalls in the analysis of prenatal treatment effects in multiparous species. Neurotoxicol Teratol 14:221-228.

Houslay MD, Sullivan M, Bolger GB (1998) The multienzyme PDE4 cyclic adenosine monophosphate-specific phosphodiesterase family: in tracellular targeting, regulation, and selective inhibition by compounds exerting anti-inflammatory and antidepressant actions. Adv Pharmacol 44:225-342.

Jarrard LE (1993) On the role of the hippocampus in learning and memory in the rat. Behav Neural Biol 60:9-26.

Kameyama T, Lee H-K, Bear MF, Huganir RL (1998) Involvement of a postsynaptic protein kinase A substrate in the expression of homosynaptic long-term depression. Neuron 21:1163-1175.

Kirk RE (1995) Experimental design: procedures for the behavioral sciences. Pacific Grove, CA: Brooks/Cole.

Ko GY, Kelly PT (1999) Nitric oxide acts as a postsynaptic signaling molecule in calcium/calmodulin-induced synaptic potentiation in hippocampal CA1 pyramidal neurons. J Neurosci 19:6784-6794.

Konradi C, Cole R, Heckers S, Hyman S (1994) Amphetamine regulates gene expression in rat striatum via transcription factor CREB. J Neurosci 14:5623-5634.

Kotter R (1994) Postsynaptic integration of glutamatergic and dopaminergic signals in the striatum. Prog Neurobiol 44:163-196.

Krinks M, Haiech J, Rhoads A, Klee C (1984) Reversible and irreversible activation of cyclic nucleotide phosphodiesterase: separation of the regulatory and catalytic domains by limited proteolysis. In: Advances in 
cyclic nucleotide and protein phosphorylation research (Strada SJ, Thompson W, eds), pp 31-47. New York: Raven.

Laemmli UK (1970) Cleavage of structural proteins during the assembly of the head of bacteriophage T4. Nature 227:680-685.

Lal S, Sharma RK, McGregor C, Macaulay RJB (1999) Immunohistochemical localization of calmodulin-dependent cyclic phosphodiesterase in the human brain. Neurochem Res 24:43-49.

Li H, Zeitler PS, Valerius MT, Small K, Potter SS (1996) GsH-1, an orphan Hox gene, is regulated for normal pituitary development. EMBO J 15:714-724.

Livingstone MS, Sziber PP, Quinn WG (1984) Loss of calcium/calmodulin responsiveness in adenylate cyclase of rutabaga, a Drosophila learning mutant. Cell 37:205-215.

Ludvig N, Burkmeister V, Jobe PC, Kincaid RL (1991) Electron microscopic immunocytochemical evidence that the calmodulin-dependent cyclic nucleotide phosphodiesterase is localized predominantly at postsynaptic sites in the rat brain. Neuroscience 44:491-500.

Malenka RC, Nicoll RA (1999) Long-term potentiation-a decade of progress? Science 285:1870-1874.

Mansuy IM, Mayford M, Jacob B, Kandel ER, Bach ME (1998) Restricted and regulated overexpression reveals calcineurin as a key component in the transition from short-term to long-term memory. Cell 92:39-49.

Mayer B, Koesling D, Bohme E (1993) Characterization of nitric oxide synthase, soluble guanylyl cyclase, and $\mathrm{C}^{2+} /$ calmodulin-stimulated cGMP phosphodiesterase as components of neuronal signal transduction. In: Advances in second messenger phosphodiesterase research (Brown BL, Dobson PRM, eds), pp 111-119. New York: Raven.

Mayford M, Wang J, Kandel ER, O'Dell TJ (1995) CaMKII regulates the frequency-response function of hippocampal synapses for the production of both LTD, LTP. Cell 81:891-904.

Miserendino M, Nestler E (1995) Behavioral sensitization to cocaine: modulation by the cyclic AMP system in the nucleus accumbens. Brain Res 674:299-306.

Monsma F, Mahan L, McVittie L, Gerfen C, Sibley D (1990) Molecular cloning and expression of a D1 dopamine receptor linked to adenylyl cyclase activation. Proc Natl Acad Sci USA 87:6723-6727.

Polli JW, Kincaid RL (1994) Expression of a calmodulin-dependent phosphodiesterase isoform (PDE1B1) correlates with brain regions having extensive dopaminergic innervation. J Neurosci 14:1251-1261.

Qui Y, Davis RL (1993) Genetic dissection of the learning/memory gene dunce of Drosophila melanogaster. Genes Dev 7:1447-1458.

Rafales L (1986) Assessment of locomotor activity. In: Neurobehavioral toxicology (Annau Z, ed), pp 54-68. Baltimore: Johns Hopkins UP.

Reed TM, Browning JE, Blough RI, Vorhees CV, Repaske DR (1998) Genomic structure and chromosome location of the murine PDE1B phosphodiesterase gene. Mamm Genome 9:571-576.

Repaske DR, Swinnen JV, Jin S-L, VanWyk JJ, Conti M (1992) A polymerase chain reaction strategy to identify and clone cyclic nucleotide phosphodiesterase cDNAs. J Biol Chem 267:18683-18688.

Saucier D, Hargreaves EL, Boon F, Vanderwolf CH, Cain DP (1996) Detailed behavioral analysis of water maze acquisition under systemic NMDA or muscarinic antagonism: nonspatial pretraining eliminates spatial learning deficits. Behav Neurosci 110:103-116.

Schenk F (1985) Development of place navigation in rats from weaning to puberty. Behav Neural Biol 43:69-85.

Sharma RK, Wang J (1985) Differential regulation of bovine brain calmodulin-dependent cyclic nucleotide phosphodiesterase isoenzymes by cyclic AMP-dependent protein kinase and calmodulin-dependent phosphatase. Proc Natl Acad Sci USA 82:2603-2607.

Sharma RK, Wang J (1986) Calmodulin and $\mathrm{Ca}^{2+}$-dependent phosphorylation and dephosphorylation of $63 \mathrm{kDa}$ subunit containing bovine brain calmodulin-stimulated cyclic nucleotide phosphodiesterase isozyme. J Biol Chem 261:1322-1328.
Skoulakis EMC, Kalderon D, Davis RL (1993) Preferential expression in mushroom bodies of the catalytic subunit of protein kinase A, its role in learning and memory. Neuron 11:197-208.

Snyder GL, Girault J-A, Chen JYC, Czernik AJ, Kebabian JW, Nathanson JA, Greengard P (1992) Phosphorylation of DARPP-32 and protein phosphatase inhibitor-1 in rat choroid plexus: regulation by factors other than dopamine. J Neurosci 12:3071-3083.

Snyder GL, Fienberg AA, Huganir RL, Greengard P (1998) A dopamine/ D1 receptor/protein kinase A/dopamine- and cAMP-regulated phosphorylation $\left(M_{\mathrm{r}} 32 \mathrm{kDa}\right) /$ protein phosphatase-1 pathway regulates dephosphorylation of the NMDA receptor. J Neurosci 18:10297-10303.

Soderling SH, Bayuga SJ, Beavo JA (1999) Isolation and characterization of a dual-substrate phosphodiesterase gene family: PDE10A. Proc Natl Acad Sci USA 96:7071-7076.

Surmeier DJ, Bargas J, Hemmings HC, Nairn AC, Greengard P (1995) Modulation of calcium currents by a D1 dopaminergic protein kinase/ phosphatase cascade in rat neostriatal neurons. Neuron 14:385-397.

Towbin H, Staehlin T, Gordon J (1979) Electrophoretic transfer of proteins from polyacrylamide gels to nitrocellulose sheets: procedure and some applications. Proc Natl Acad Sci USA 76:4350-4354.

Traficante L, Friedman E, Oleshansky M, Gerson S (1976) Dopaminesensitive adenylate cyclase and cAMP phosphodiesterase in substantia nigra and corpus striatum of rat brain. Life Sci 19:1061-1066.

Tsou K, Snyder G, Greengard P (1993) Nitric oxide/cGMP pathway stimulates phosphorylation of DARPP-32, a dopamine- and cAMPregulated phosphoprotein, in the substantia nigra. Proc Natl Acad Sci USA 90:3462-3465.

Upchurch M, Wehner JM (1988) Differences between inbred strains of mice in Morris water maze performance. Behav Genet 18:55-68.

Wu J, Wang Y, Rowan MJ, Anwyl R (1998) Evidence for involvement of the cGMP-protein kinase $\mathrm{G}$ signaling system in the induction of longterm depression, but not long-term potentiation, in the dentate gyrus. J Neurosci 18:3589-3596.

Xu M, Moratalla R, Gold L, Hiroi N, Koob G, Graybiel A, Tonegawa S (1994) Elimination of cocaine-induced hyperactivity and dopaminemediated neurophysiological effects in dopamine D1 receptor mutant mice. Cell 79:945-955.

Yan C, Bentley JK, Sonnenburg WK, Beavo JA (1994) Differential expression of the $61 \mathrm{kDa}$ and $63 \mathrm{kDa}$ calmodulin-dependent phosphodiesterases in the mouse brain. J Neurosci 14:973-984.

Yan C, Zhao AZ, Bentley JK, Loughney K, Ferguson K, Beavo JA (1995) Molecular cloning and characterization of a calmodulindependent phosphodiesterase enriched in olfactory sensory neurons. Proc Natl Acad Sci USA 92:9677-9681.

Yan C, Zhao AZ, Bentley JK, Beavo JA (1996) The calmodulindependent phosphodiesterase gene PDE1C encodes several functionally different splice variants in a tissue-specific manner. J Biol Chem 271:25699-25706.

Yan Z, Surmeier D (1997) $\mathrm{D}_{5}$ dopamine receptors enhance $\mathrm{Zn}^{2+}$. sensitive $\mathrm{GABA}_{\mathrm{A}}$ currents in striatal cholinergic interneurons through a PKA/PP1 cascade. Neuron 19:1115-1126.

Yin JCP, Wallach JS, Del Vecchio M, Wilder EL, Zhou H, Quinn WG, Tully T (1994) Induction of a dominant negative CREB transgene specifically blocks long-term memory in Drosophila. Cell 79:49-58.

Yuasa K, Kanoh Y, Okumura K, Omori K (2001) Genomic organization of the human phosphodiesterase PDE11A gene. Evolutionary relatedness with other PDEs containing GAF domains. Eur J Biochem 268:168-178.

Zhou Q-Y, Palmiter RD (1995) Dopamine-deficient mice are severely hypoactive, adipsic, and aphagic. Cell 83:1197-1209.

Zola-Morgan S, Squire LR (1993) Neuroanatomy of memory. Annu Rev Neurosci 16:547-563. 